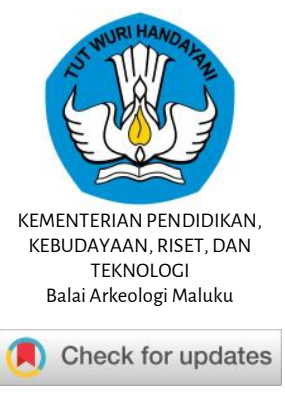

Kapata Arkeologi, 17(2) 2021, 71-84

p-ISSN: 1858-4101, e-ISSN: 2503-0876

KAPATA ARKEOLOGI

SCIENTIFIC JOURNAL OF ARCHAEOLOGY AND CULTURAL STUDIES

Accredited by the Indonesian Ministry of Research, Technology, and Higher Education (RISTEKBRIN)
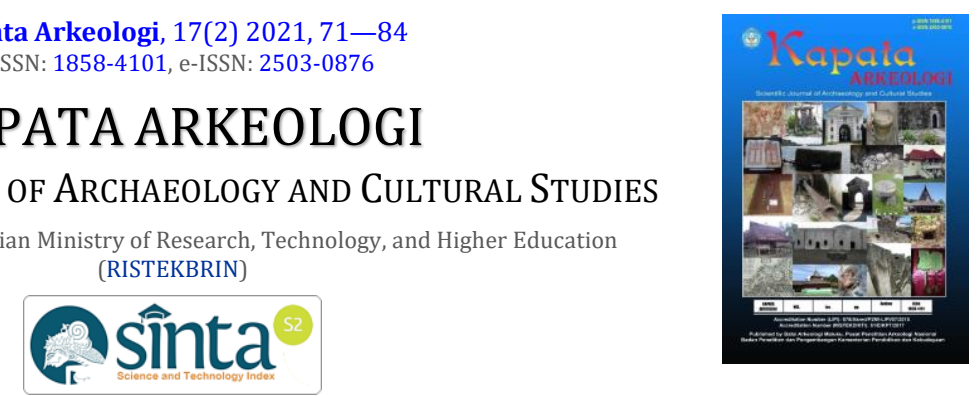

http://kapata-arkeologi.kemdikbud.go.id/

\title{
Sungai Batu Archaeological Complex as A Major INDUSTRIAL AREA FOR THE KEDAH TUA KINGDOM BASED ON CORE DRILLING DATA
}

\author{
Mohd Hasfarisham Abd Halim *, Shyeh Sahibul Karamah Masnan (D), Nur Khairunnisa Talib, \\ Mokhtar Saidin \\ Universiti Sains Malaysia \\ Center for Global Archaeological Research, Pulau Pinang 11800, Malaysia \\ *mhasfarisham@gmail.com \\ Received: 16/06/2021; revisions: 22/07 — 18/11/2021; accepted: 12/12/2021
}

\begin{abstract}
Sungai Batu archaeological complex is a group of various settlements and exchange sites located in the Bujang Valley, which developed as a polity from the 2nd to 14th century AD. The archaeological findings at Sungai Batu suggest the position of the area as a polity or settlement specializing in primary iron production, which involved the activities of iron mining and smelting. Field research involving core drilling methods applied in the area of Sungai Batu Archaeological Complex with the main purpose of obtaining primary data related to its potential as a major industrial area of Kedah Tua Kingdom. This is because current archaeological evidence reveals that this area has been used as a major and advanced iron smelting workshop for the Kedah Tua kingdom since $788 \mathrm{BC}$. Analysis of core drilling (soil samples) clearly shows that this area represented the part of a large ancient marine bay before the sea level decreased. It was changed to become a river estuary allowing settlements to be established. Sungai Batu Archaeological Complex also exposed many raw materials such as iron ore for the smelting industry and alluvium for making a brick. It has developed into a flourishing industrial complex since 788 BC.
\end{abstract}

Keywords: Sungai Batu Archaeological Complex; core drilling; iron industry; raw material; Kedah Tua Kingdom

\section{INTRODUCTION}

This research will obtain primary data related to the sustainability of Kedah Tua as the world's iron industry based on core drilling data. In order to obtain data, field research involving survey, mapping, and core drilling methods are applied to detect preliminary data about the potential and importance of this area to the world iron industry trade. Surveys are conducted by studying a topography and geology map to determine the best location for core drilling at the Sungai Batu Archaeological Complex.

Based on voyage and trade records by I-Tsing (1896), Hoyland \& Gilmour (2006), and Thilakavathy (2019), clearly confirms the Kedah Tua Kingdom was played as a world major iron production. Archaeological research at the Sungai Batu Archaeological Complex reveals the evidence that early people at Sungai Batu Archeological Complex already had the skills and technology to do iron smelting activities in this area before being exported.

\section{Geological Formation in The Sungai Batu Archaeological Complex Area}

The Sungai Batu complex is formed in two formations, the Jerai Formation and the Mahang Formation (Figure 3), which are around 550 million years old (Almashoor, 1974). According to Bradford (1972), the Mahang Formation is in the Middle Ordovician to Middle Devonian Period, while the Jerai Formation is in the Late Cambrian to Middle Ordovician Period. The Mahang Formation generally contains carbon and iron oxide. The geological content of the Mahang Formation is also interpreted to include minerals of high economic value (Andika, Saad, Saidin, Muztaza, $\&$ Amsir, 2018). The discovery of economically valuable minerals such as hematite, magnetite, cassiterite, tantalum, copper, gold, and other minerals is due to the occurrence of late fission after Jerai granite fission occurred (Figure 5). 


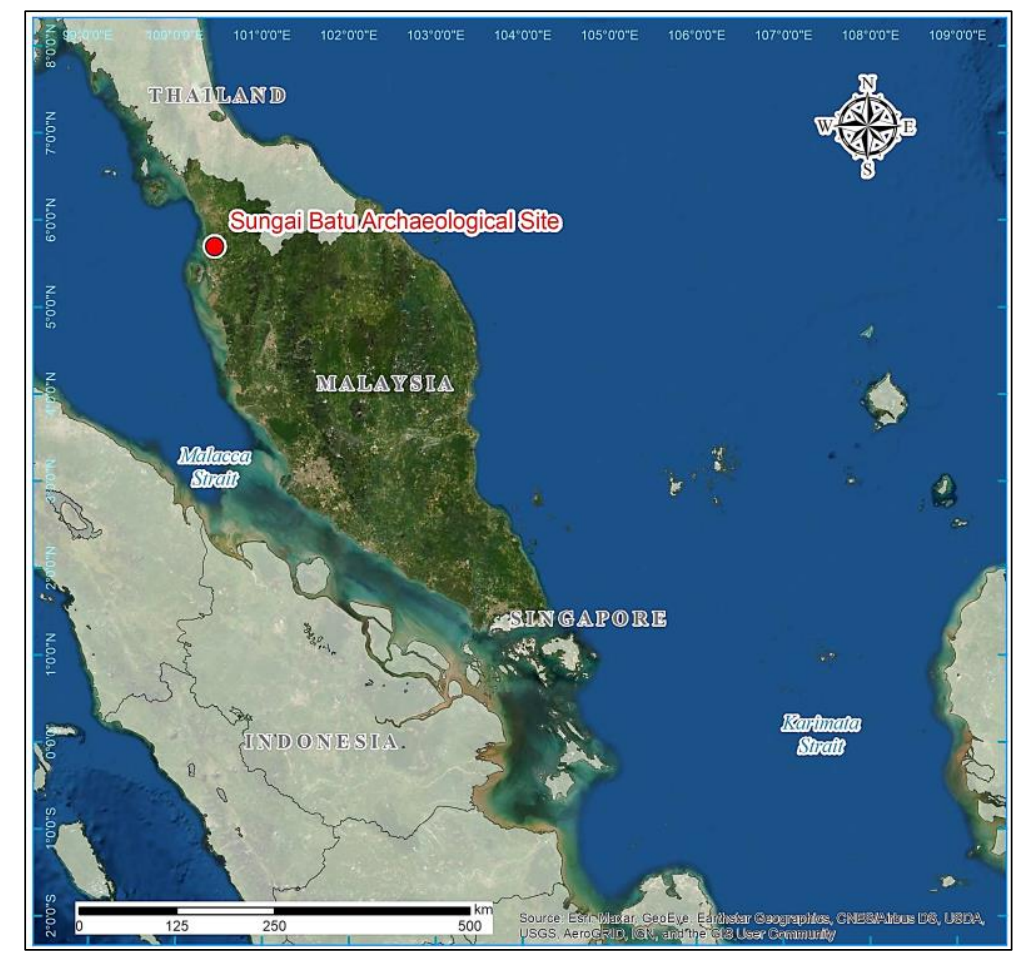

Figure 1. Location of Sungai Batu Archaeological Site

(Source: ArcGIS Database, 2019)

Bradford (1972) and Almashoor (1974) also suggested that the Jerai Formation was divided into three facies: argillite, arenite, and quartz porphyry facies, which are only present in the Mount Jerai area. The iron-based economy is strengthened by the discovery of economically valuable minerals used as the main iron smelting material in the Sungai Batu Archaeological
Complex. These minerals have filled cracks in the existing Jerai granite, Mahang Formation, and Jerai Formation. It generally provides information on the potential of the Sungai Batu area itself in supplying raw material of iron smelting for the development of Kedah Tua iron-based economy.

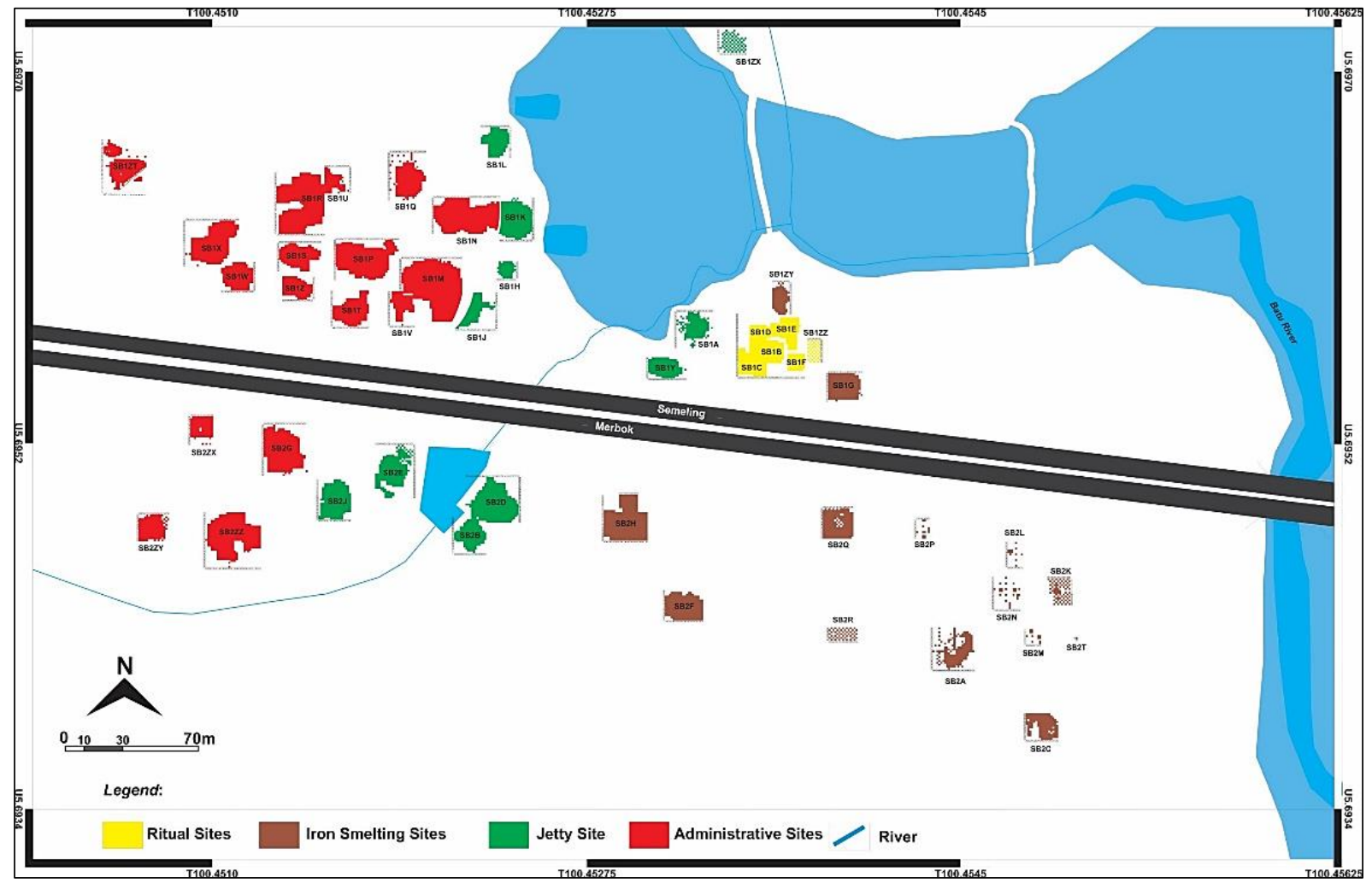

Figure 2. The iron smelting workshop, jetty, administrative and ritual sites at the Sungai Batu Archaeological Complex which suggests it as the main iron industry area of Kedah Tua

(Source: Saidin, 2016) 


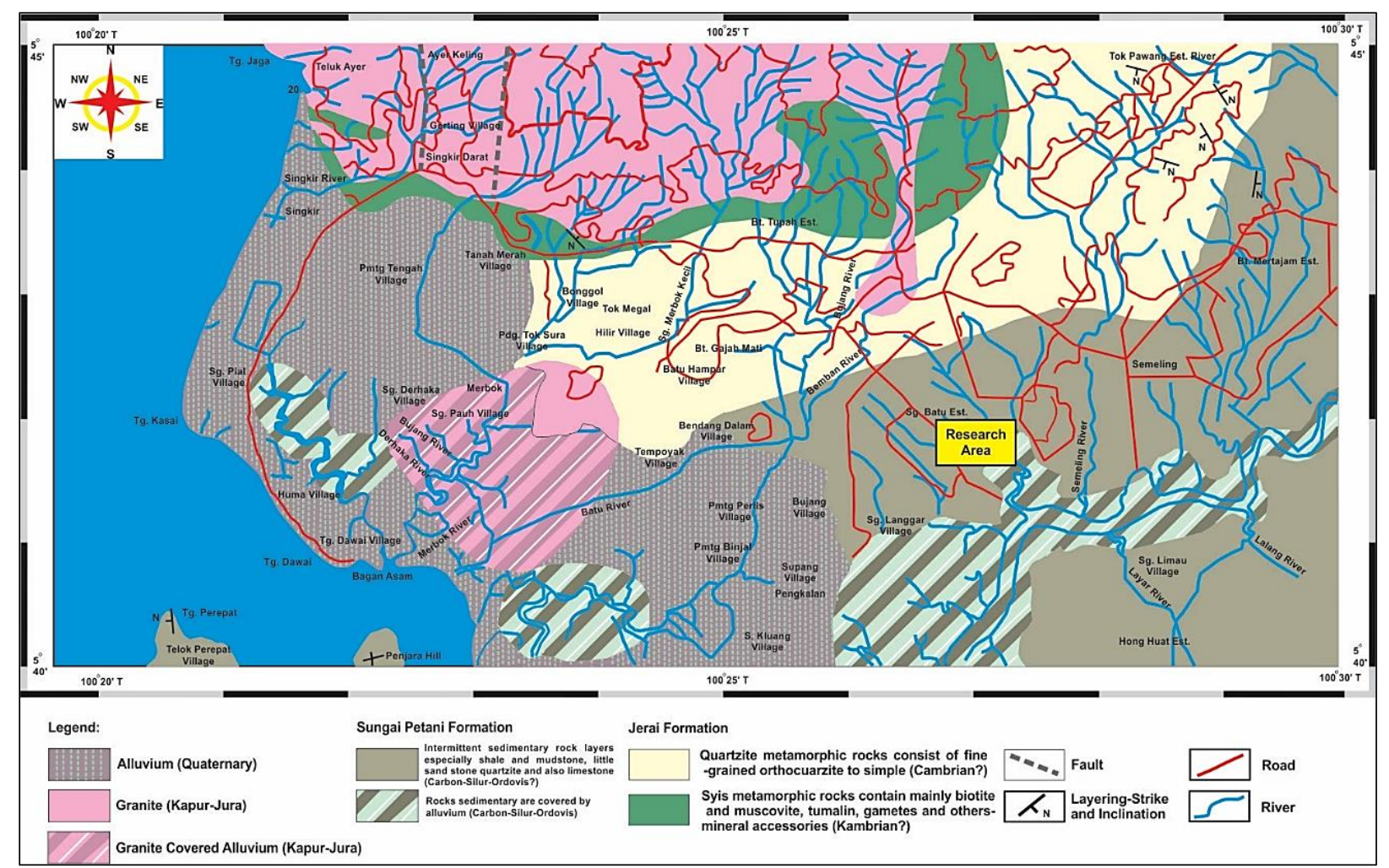

Figure 3. General geology of the Sungai Batu Archaeological Complex area, which is formed by two formations, namely the Mahang and Jerai Formations. The marked rectangular area is the Sungai Batu Archaeological Complex

(Source: Talib, 2009)

Quaternary sediments in the area Mount Jerai consist of two sequences, the surface consisting of sediment not consolidated and sediment deeper below the surface. Surface sediments are formed by named Sugar Formation marine alluvium and terrestrial alluvium like a Beruas Formation.

In the Quaternary period, about 2 million years ago, the earth of Jerai and other regions in Southeast Asia have experienced sea level rise and fall during that time. During the Holocene Epoch, which is around 10,000 years old, sea-level changes were recorded in the rising range up to more than 5 meters and a decrease of up to 25 meters from the level the sea now. A maximum height of $5 \mathrm{~m}$ is reached around 5,000 to 7,000 years ago (Sathiamurthy \& Voris, 2006).

The position of the ancient coastline of the Quaternary period has changed several times progressively due to the progradation of sediments that took place along the coast. In line with the ancient coastline changes above, the Sungai Merbok estuary has also undergone significant evolution throughout the Quaternary period. The estuary was initially been a large bay 2,600 years ago known as Kedah Bay.

\section{METHODS}

Survey method to obtain data on raw materials (brick sample) used in making brick to carried out in the vicinity of the Sungai Batu Archaeological Complex. To prove the research on geological maps of Sheet 2-1/2 and
$2-1 / 6$, this study involves several methods to gather information. The survey activities involved the use of global positioning systems (GPS) and notebooks to record information while the data was observed.

In addition, the core drilling process is carried out to prove the existence of ancient rivers and raw materials

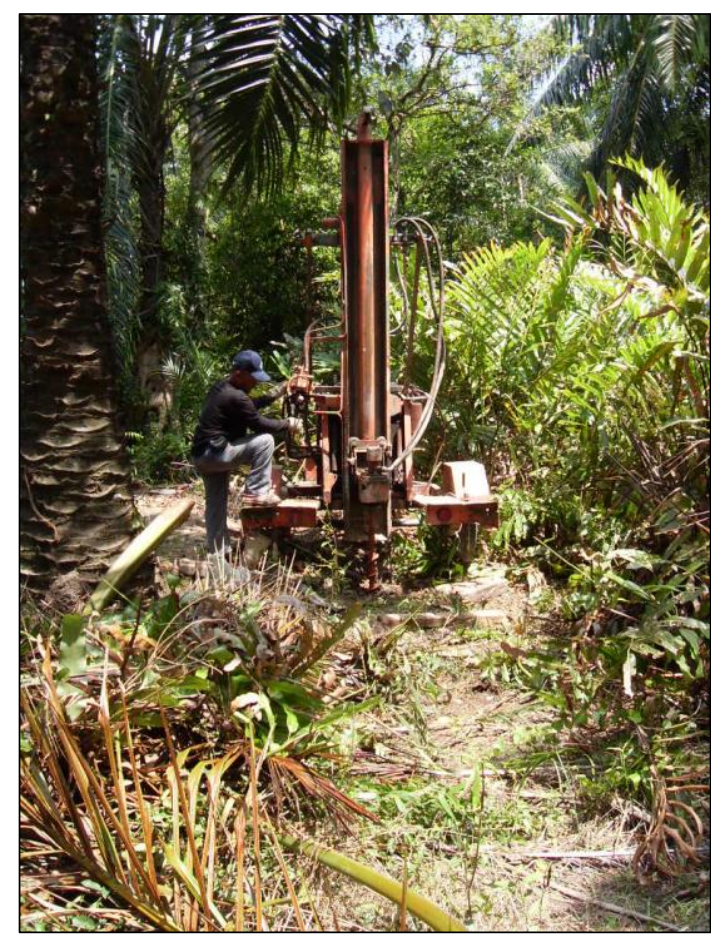

Figure 4. Core drilling process through hydraulic drive rotation method using flight-mounted solid auger applied in Sungai Batu Archaeological Complex 


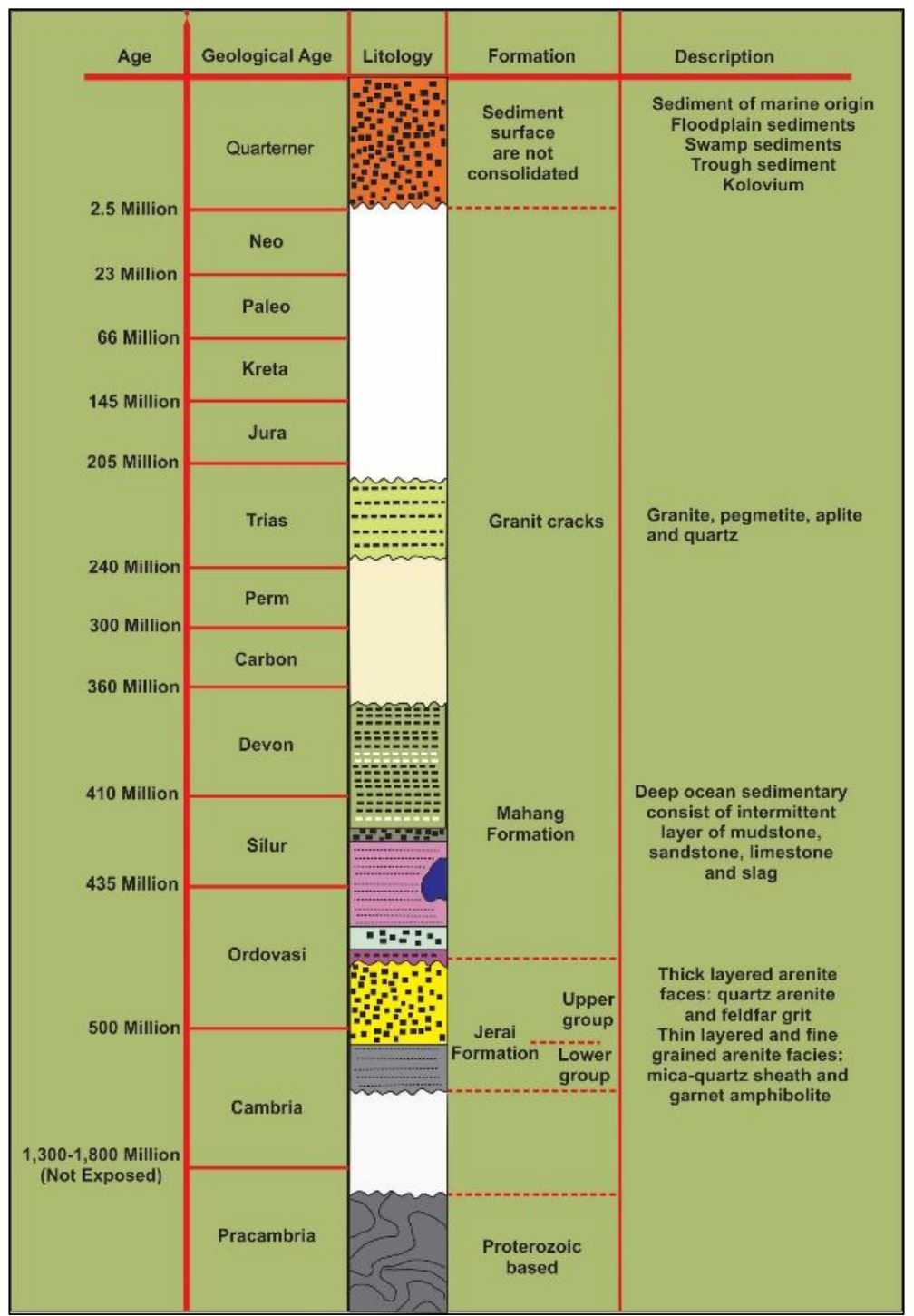

Figure 5. Geological column showing the occurrence of late fractures after granite fractures that produce economically valuable minerals

(Source: Bradford, 1972)

for the manufacture and construction of monuments in this area. Gemco brand drilling machinery is used with hydraulic drive rotation method using a flight-mounted solid auger (Figure 4) is used while soil sample is drilled. The drilling locality holes were determined through electrical resistivity data from geophysical surveys and were located within the Sungai Batu Archaeological Complex so that the data could be used in interpreting the potential of the area in the world iron smelting industry.

\section{RESUlT AND DISCUSSION}

\section{Survey Data and Analysis of Iron Smelting Basic Materials}

Based on the study on the geological map of Sheet $2-1 / 2$ and 2-1/6, the survey activities were conducted in the vicinity of Bujang, UiTM Merbok, Kampung Batu 5, Kampung Sungai Batu Besi, Bukit Tupah, and Semeling. Interpretation of the geological map of the area shows a pattern of distribution of high iron ore, hematite, and magnetite minerals. Based on this interpretation, these areas were chosen as the survey area's focus. The survey results show that the areas of Bukit Tupah, UiTM Merbok, and Kampung Batu 5 record a large amount of iron ore distribution, especially stanum (Sn) and cassiterite minerals (Figure 6). Cassiterite is the main mineral for the characterization of tin ores (Ngadenin, Indrastomo, Karunianto, \& Rakhma, 2017). In addition, there is an active open-pit mine in Bukit Tupah. Naizatul (2012) study through X-Ray Fluorescence (XRF) analysis clearly shows that iron ore from UiTM Merbok, Bukit Tupah, and Kampung Batu 5 was used in the Kedah Tua iron industry in Sungai Batu. The location is less than six kilometers from the Sungai Batu Archaeological Complex.

Furthermore, it also examines data related to iron industry fuels for iron ore smelting purposes. Based on the topographic map, the area around the Merbok River is clearly exposed as a mangrove swamp area of more than 10 square kilometers, which indicates that it was 


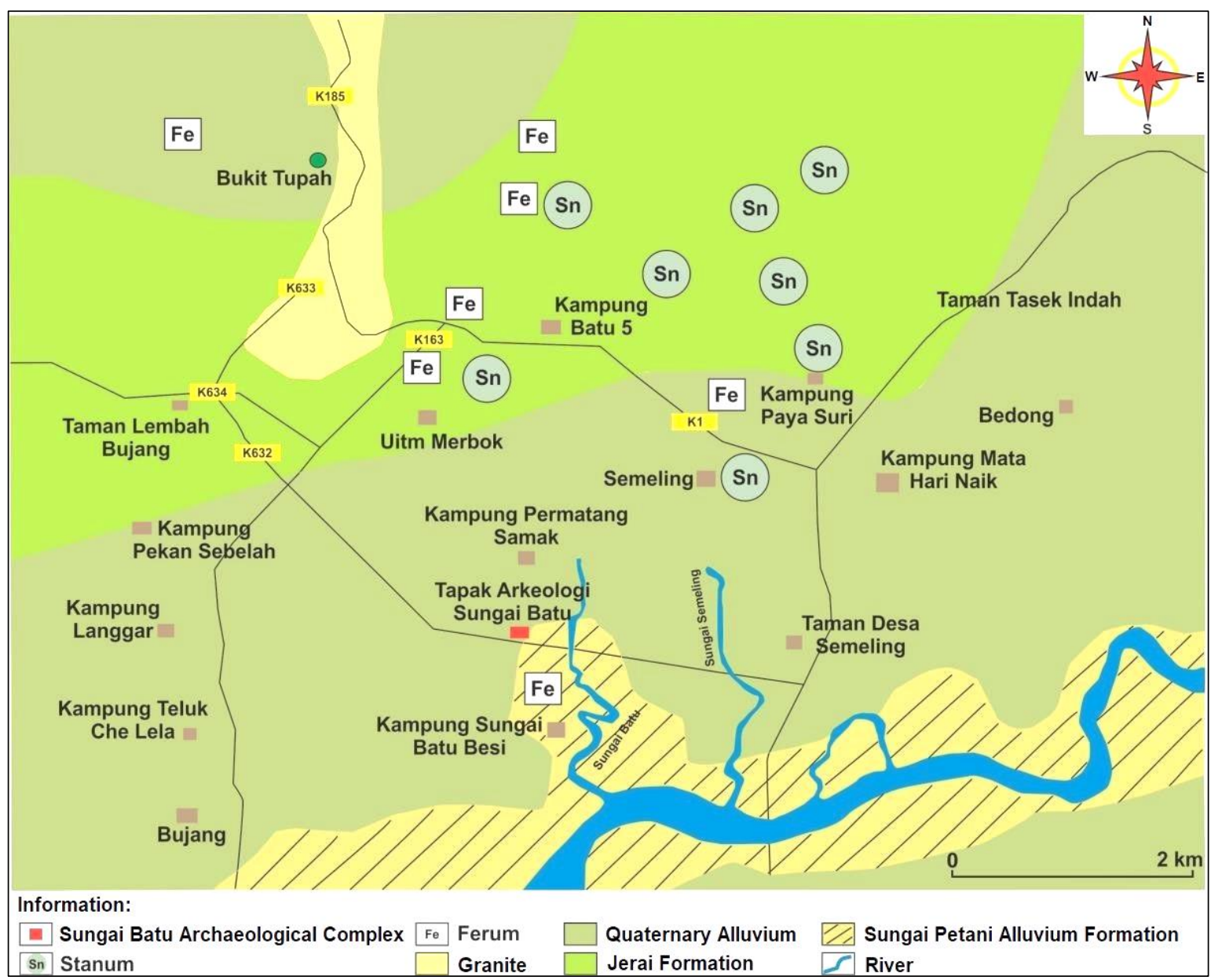

Figure 6. Geological map of the Sungai Batu Archaeological Complex where iron minerals were found for ancient iron smelting (Source: Naizatul, 2012)

used in the Kedah Tua iron industry (Yusoh, Saad, Saidin, Muhammad, Anda, Ashraf, et al., 2018). The results of Naizatul \& Saidin (2019) study on the mapping of SEMEDX scientific analysis fuel on the moisture of coal samples (Table 1) show a carbon content of around 50.51 to $68.81 \%$, which is close to the percentage of good quality coal used in iron smelting activities. The calcium
(Ca) presence in all analyzed charcoal samples also indicated that the charcoal was taken from the same source. This can be seen from the texture of the charcoal, which is dense and porosity. Photomicrographs of the charcoal samples (Figure 7) also revealed that the charcoal came from hardwood types.

Table 1. SEM-EDX analysis shows the percentage of moisture content in charcoal samples

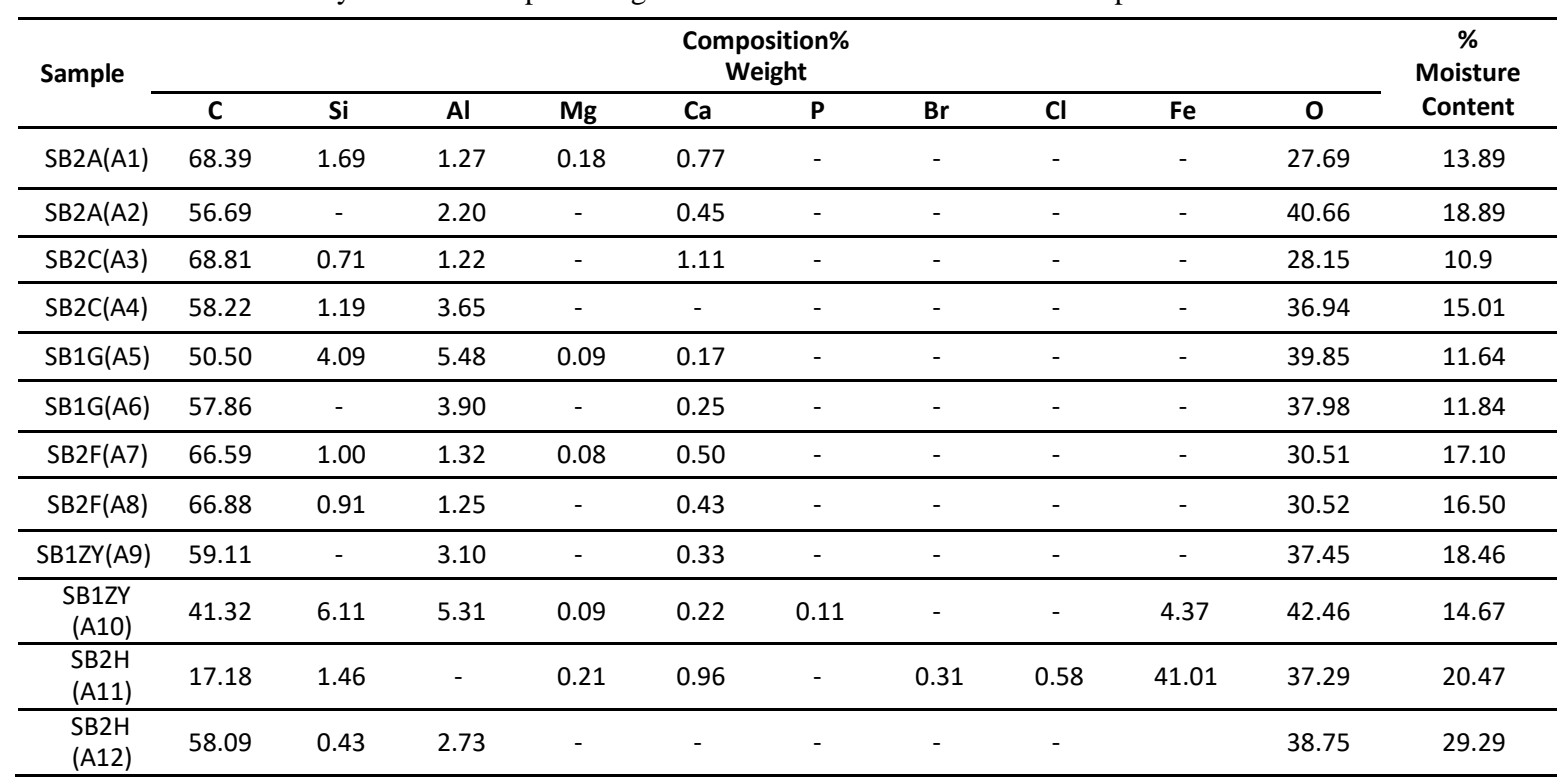

Source: Naizatul \& Saidin, 2019 
Based on SEM-EDX analysis, Merbok mangroves may have been used as the primary fuel in the Kedah Tua iron smelting industry at the Sungai Batu Archaeological Complex. Based on the survey of the basic materials data and scientific analysis, it is clear that the Sungai Batu Archaeological Complex area has the potential to become a successful iron industrial area because of its environmental resources to supply the basic materials for iron smelting, such as iron ore, magnetite, hematite, and mangroves as fuel.

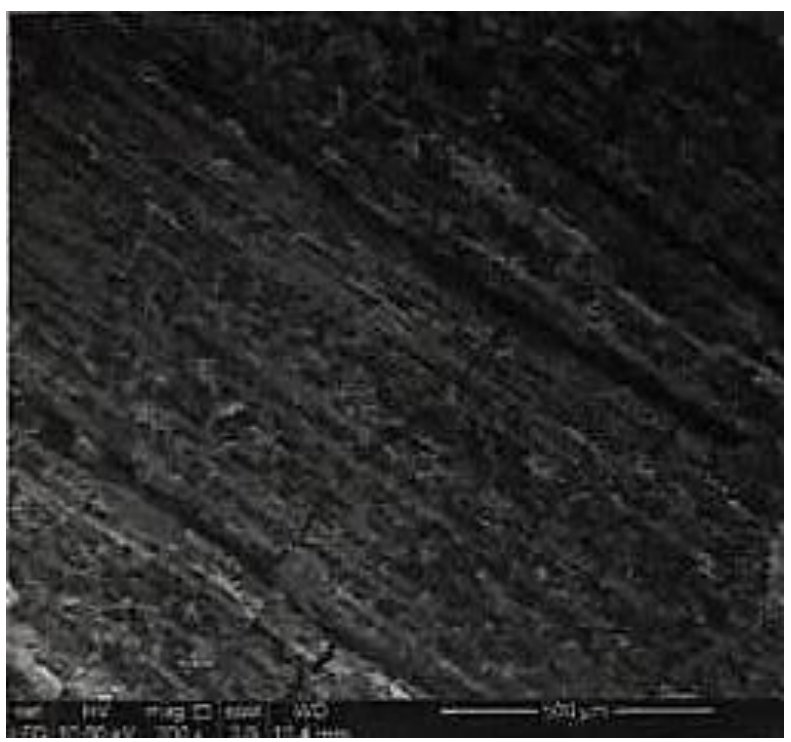

Figure 7. Photomicrograph of charcoal from an iron smelting location showing iron smelting fuel taken from hardwood types

(Source: Naizatul \& Saidin, 2019)
In addition, this area also has a wide river and allows the trade process to run effectively (Naizatul \& Saidin, 2018). Core drilling has been carried out in the Sungai Batu area to obtain data regarding the presence of river flows and the abundance of alluvial resources to make and construct monuments in this area. The data will be discussed further in this study.

\section{Analysis of Core Drilling Data in Sungai Batu Archaeological Complex}

In order to obtain data related to the sedimentation process that took place in the area of the Sungai Batu Archaeological Complex, core drilling activities were carried out. A total of 11 locality holes were selected to undergo the deep drilling method (Figure 8). The locality hole was also taken by using GPS (Global Positioning System) coordinate to map the locality. The drilling process was carried out in collaboration with a group of experts from the Jabatan Mineral dan Geosains Malaysia, Negeri Perak.

Each locality hole was drilled to the base layer, and soil samples were taken to collect sedimentation stratigraphic data that has occurred in this area. Each soil change was recorded during the core drilling based on the soil sample and locality. Data related to composition, color (using a Munsell soil clour book), and toughness of the soil were recorded to enable a comparison of the sedimentary environment and the organic and mineral content of each sample. The primary data obtained will then be processed to generate soil sequence logs.
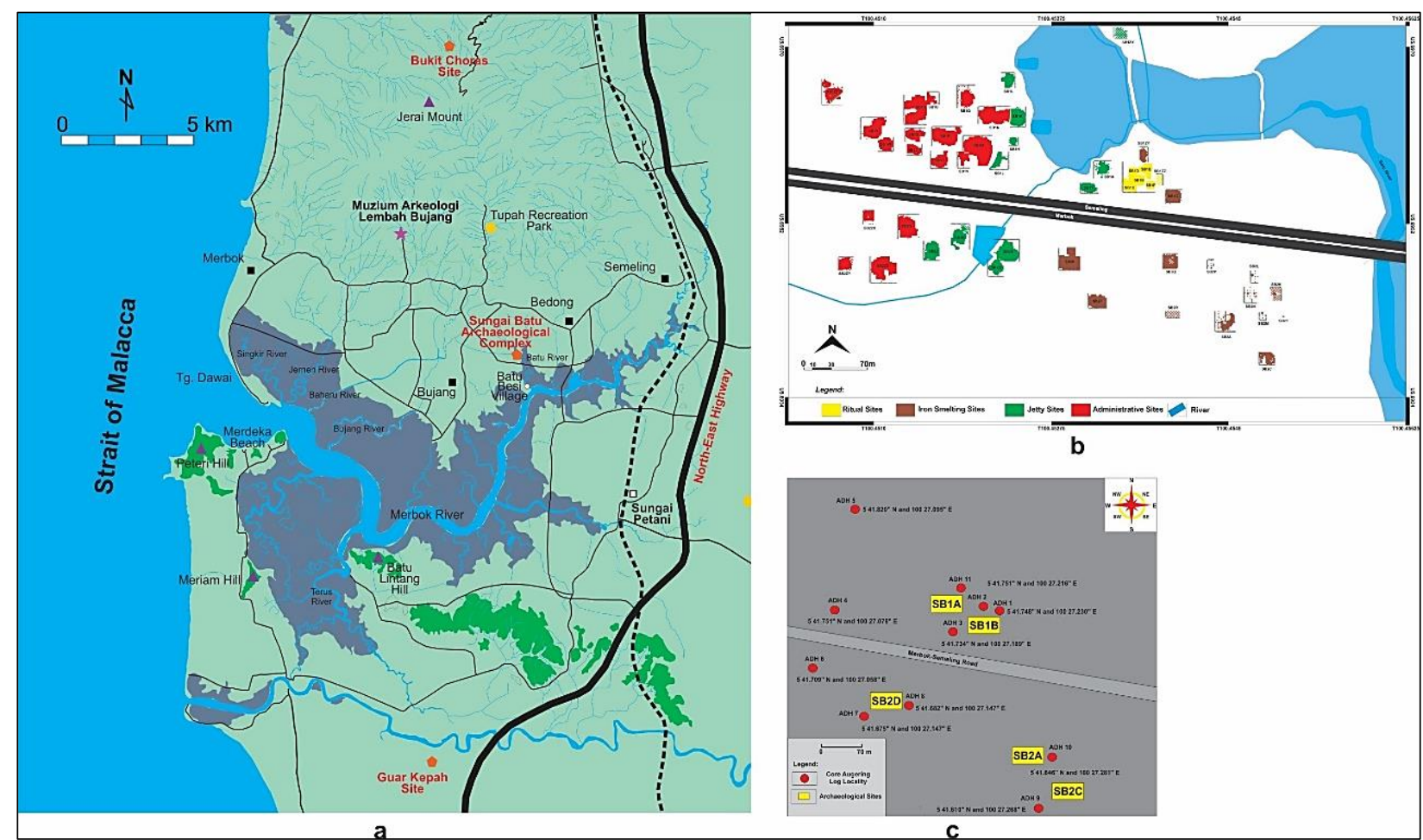

Figure 8. Sungai Batu Archaeological Site (a, b) in Lembah Bujang and core drilling locality location (c) in Sungai Batu Archaeological Complex to identify its potential as an industrial area

(Source: Talib, 2009) 


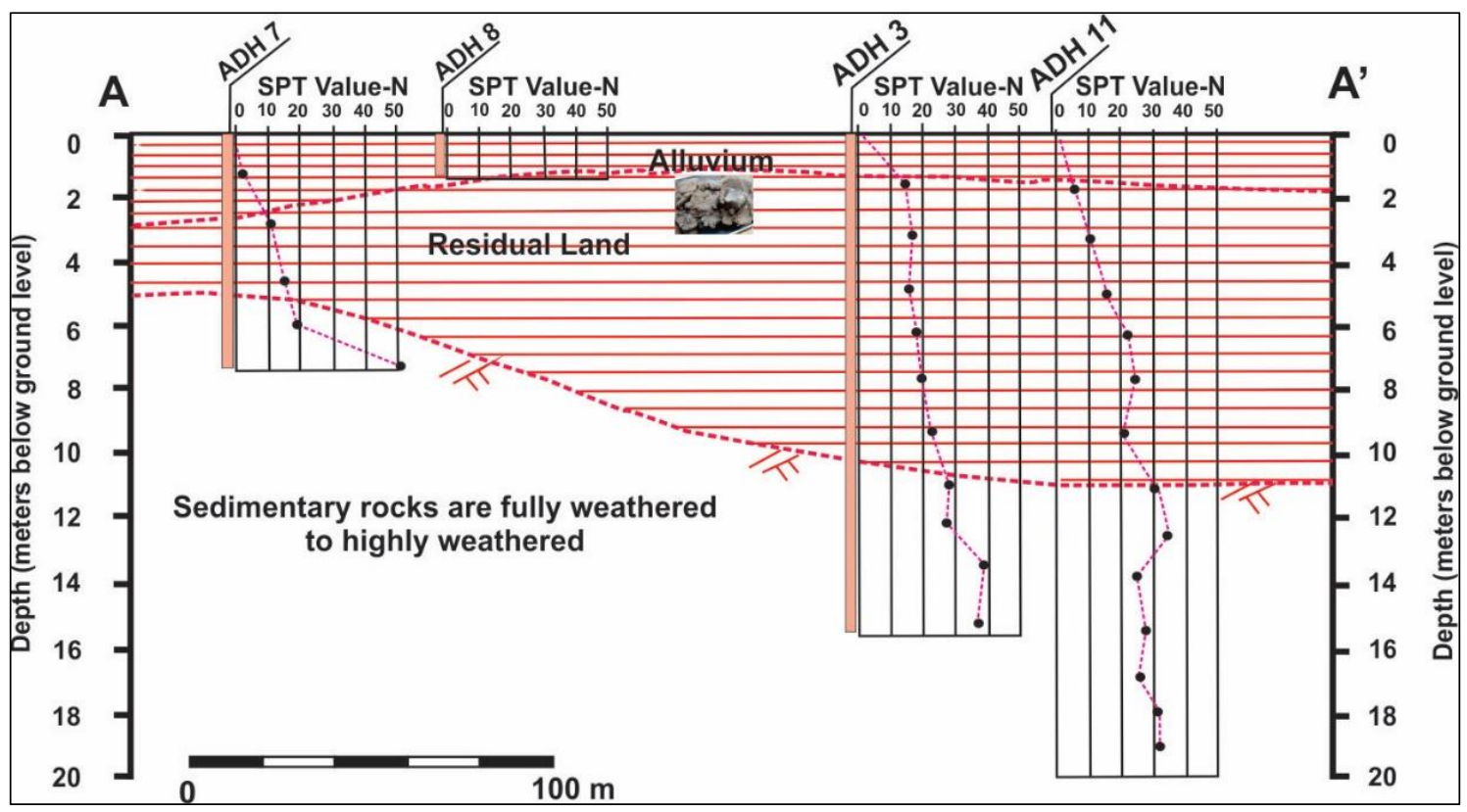

Figure 9. Sub-surface cross-section of the core drilling at Sungai Batu Archaeological Complex

The soil sequence logs obtained allow information related to ancient river flows to be known and recorded. In addition, the results of this core drilling also enable the recording of data related to alluvial deposition to be recorded. The deposition of alluvium that occurs in this area will eventually indicate the abundance of alluvium in this area that is used in the process of manufacturing and construction of monuments.

The results of core drilling carried out on 11 drilling localities suggest that the Sungai Batu Archaeological
Complex area consists of several sediments such as alluvial sediments, soil layers, and sedimentary rocks that have been fully weathered and highly weathered (Figure 9). The alluvial sediment is about 3 meters thick except in the locality of ADH9, which reaches a thickness of 4 meters.

Fully to highly weathered sedimentary rocks are characterized by clay or silt rocks that have similar characteristics to the argillite facies of the Mahang Formation and have a high iron oxide content (Bradford,

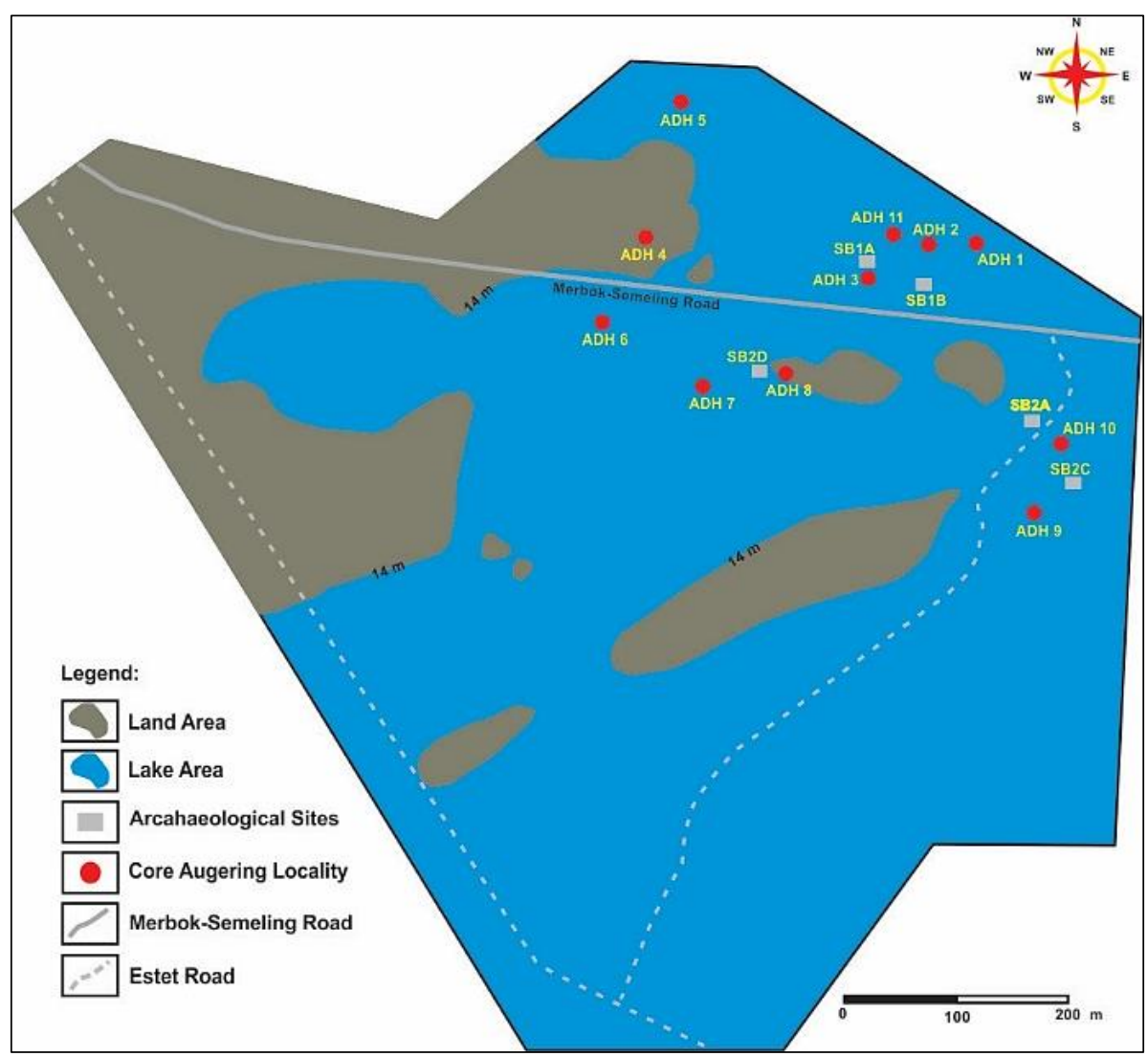

Figure 10. Apart of the ancient marine bay environment in Sungai Batu Archaeological Complex based on core drilling data 
1972). This layer is found at a depth of 5.0-18.5 meters, filling cracks in the rock as a minor element.

Based on the drilling logs ADH3, ADH 5, ADH6, ADH7, ADH9, and ADH10 (Figure 11) suggest the existence of a marine clay at 0.5 meters to 4.5 meters and the sea level at that time is 14 meters increase compared with currently sea level (Figure 10). This means that almost the entire Sungai Batu site was still under sea level or too swampy and was not suitable for settlement and industry.

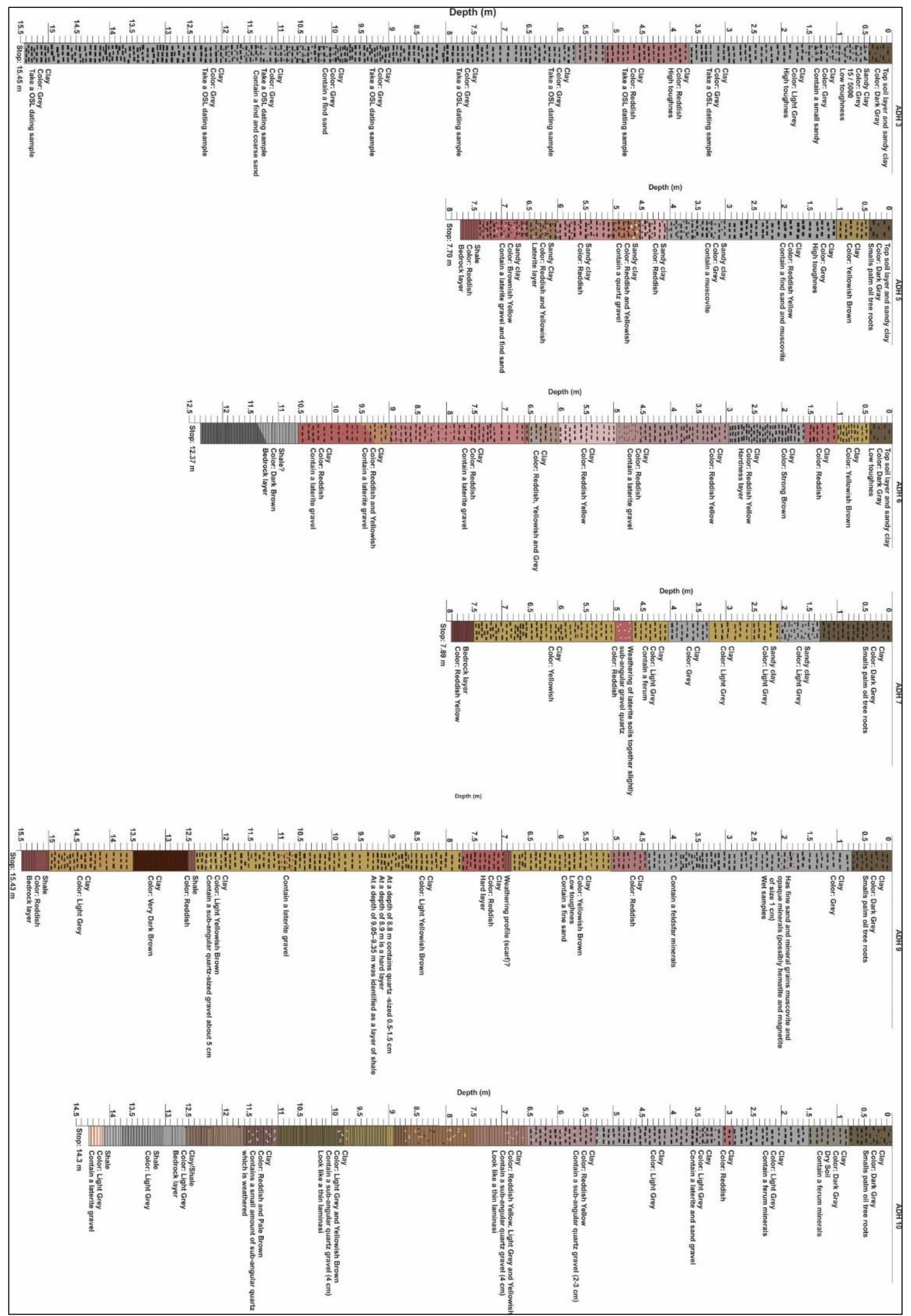

Figure 11. Stratigraphic log sequence of drilling locality ADH3, ADH5, ADH6, ADH7, ADH9, and ADH10 at Sungai Batu Archaeological Complex 


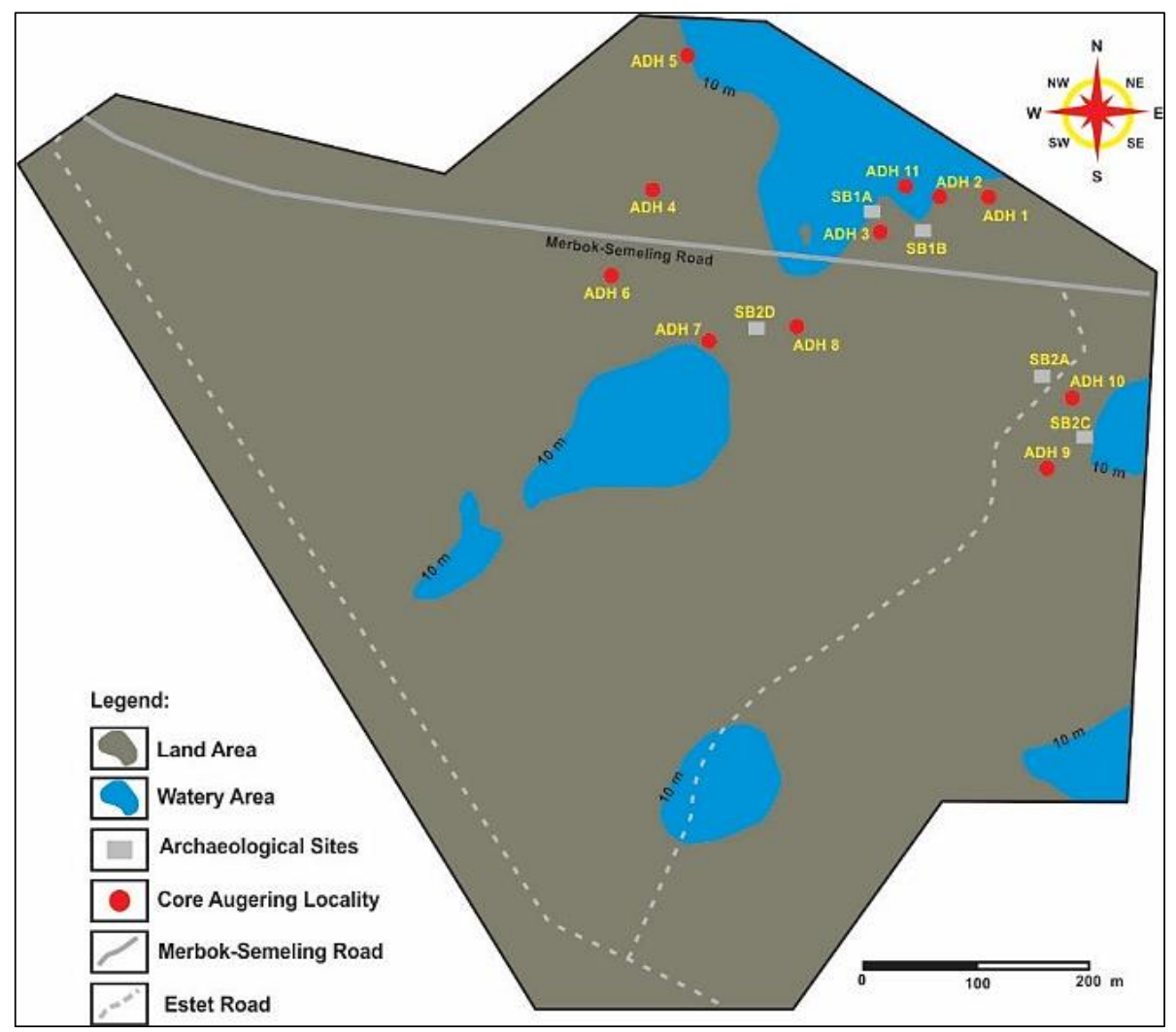

Figure 12. The environment of Sungai Batu Archaeological Complex, which shows the sea level began to fall and land began to appear, which allows this area to be inhabited as an industrial area

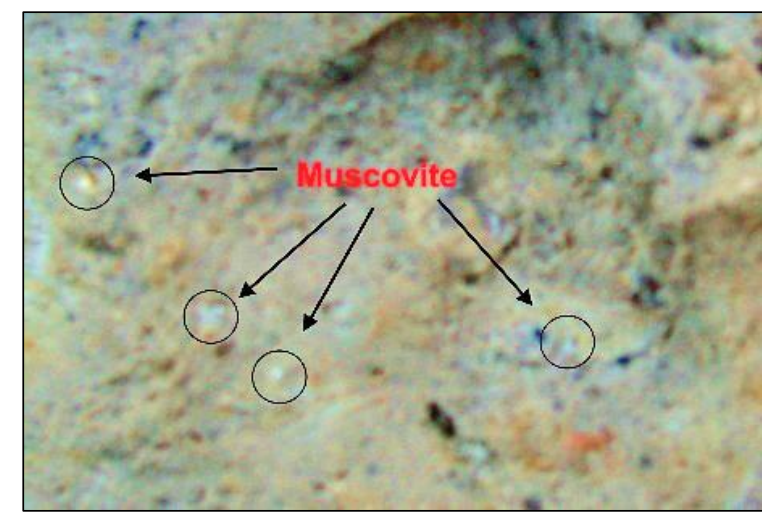

Figure 13. Results of core drilling showing the presence of muscovite (black circle)

(Source: Talib, 2009)

After the decrease of sea level, the flow of this lake dried up, and then there was an ancient river in the area of Sungai Batu (Yusoh, Saad, Saidin, Muhammad, Anda, Ismail, et al., 2018). The settlement began, which eventually developed into an iron industry. This is reinforced by the discovery of muscovite in alluvial sediments (Figure 13) on drilling logs ADH5, ADH 9 and the formation of iron clots on drilling logs ADH1 and ADH 2 (Figure 16). This is due to the sedimentation of ancient river flows from Jerai Hill (Figure 12) that once existed in this area.

The ancient large river flow is also proposed to be similar to the current swampy area (Ihsan et al., 2015). This is clearly visible on the stratigraphic layer at the SB1A jetty site (Ahmad, 2016), revealing a mud

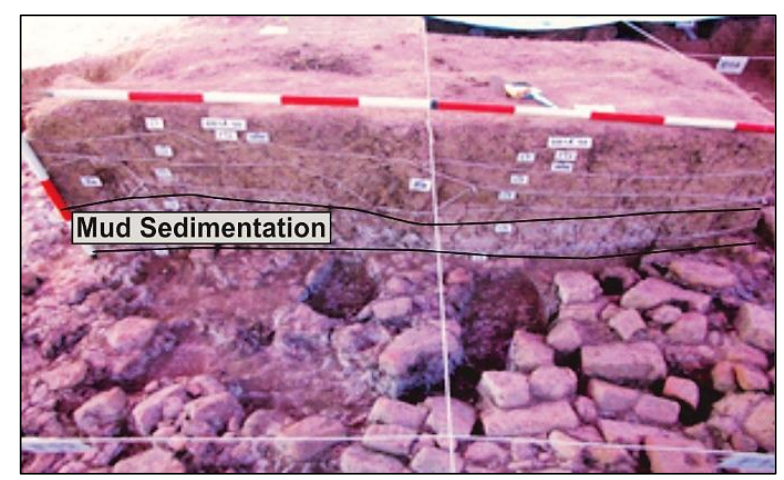

Figure 14. Mud sedimentation deposits on the stratigraphic layer at the SB1A jetty site located on the riverbank of Batu River

(Source: Zolkurnian, 2009)

sedimentation layer (Figure 14). The mud sedimentation is also seen on the drilling logs $\mathrm{ADH} 1, \mathrm{ADH} 2, \mathrm{ADH} 5$, and ADH10 (Talib, 2009), which further strengthens the

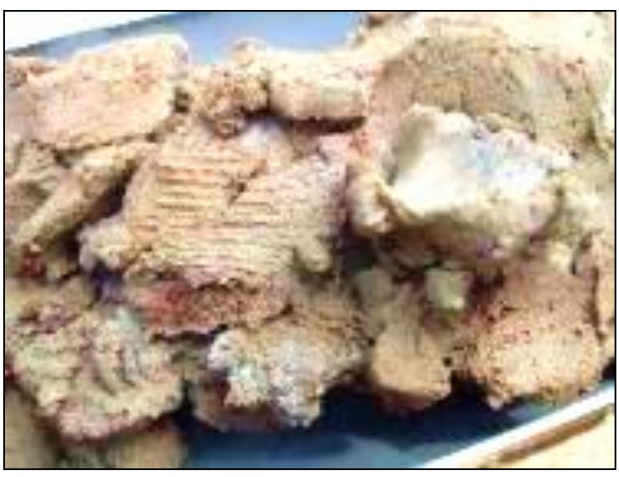

Figure 15. Dominant alluvial sediments obtained during the core drilling process 
interpretation related to the existence of large ancient river flow in the area around 100 meters width.

In addition, this core drilling data also clearly revealed alluvial sediments (Figure 15) around 3-4.5 meters, indicating an abundance of clay raw material for the manufacture and construction of monuments in the Sungai Batu Archaeological Complex. X-Ray Fluore- scence (XRF) major (Table 2) and trace elements (Table 3) analysis of soil and brick samples also showed similarities in elemental content. This strengthened the interpretation related to the use of raw materials in the Sungai Batu Complex area in the manufacturing and construction of jetty, syahbandar, and ritual monuments.

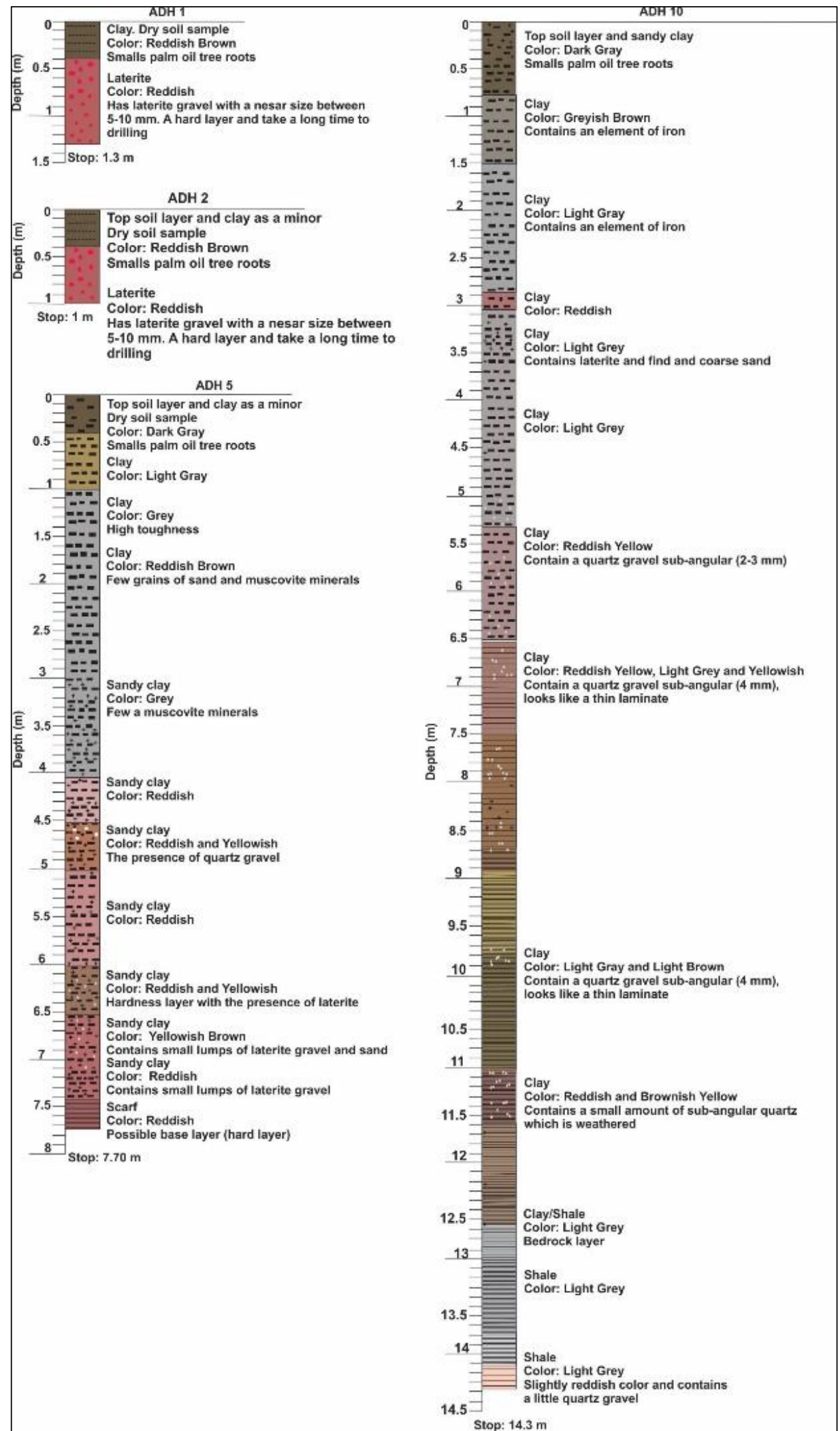

Figure 16. Stratigraphic log sequence of $\mathrm{ADH} 1, \mathrm{ADH} 2, \mathrm{ADH} 5$ and $\mathrm{ADH} 10$ showing the presence of mud sedimentation layers 
Table 2. XRF major element analysis of clay and brick samples at Sungai Batu Archaeological Complex

\begin{tabular}{|c|c|c|c|c|c|c|c|c|c|c|}
\hline \multirow{2}{*}{ SAMPLE } & \multicolumn{10}{|c|}{ ELEMENT CONTENT (\%) } \\
\hline & $\mathrm{SiO}_{2}$ & $\mathrm{TiO}_{2}$ & $\mathrm{Al}_{2} \mathrm{O}_{3}$ & $\mathrm{Fe}_{2} \mathrm{O}_{3}$ & MnO & MgO & $\mathrm{CaO}$ & $\mathrm{Na}_{2} \mathrm{O}$ & K2O & $\mathrm{P}_{2} \mathrm{O}_{5}$ \\
\hline \multicolumn{11}{|l|}{ Clay } \\
\hline 1 & 75.77 & 0.78 & 16.00 & 1.80 & 0.01 & 0.48 & 0.03 & 0.06 & 0.77 & 0.02 \\
\hline 2 & 75.85 & 0.74 & 15.52 & 1.73 & 0.01 & 0.44 & 0.02 & 0.07 & 0.72 & 0.02 \\
\hline 3 & 71.97 & 0.79 & 17.04 & 1.89 & 0.01 & 0.46 & 0.03 & 0.06 & 0.76 & 0.03 \\
\hline 4 & 69.57 & 0.83 & 18.05 & 1.88 & 0.01 & 0.54 & 0.02 & 0.06 & 0.83 & 0.01 \\
\hline 5 & 69.76 & 0.83 & 18.05 & 1.88 & 0.01 & 0.54 & 0.02 & 0.06 & 0.83 & 0.01 \\
\hline 6 & 74.31 & 0.76 & 16.03 & 1.90 & 0.01 & 0.48 & 0.03 & 0.08 & 0.74 & 0.02 \\
\hline 7 & 73.05 & 0.77 & 14.80 & 1.64 & 0.01 & 0.42 & 0.04 & 0.06 & 0.66 & 0.06 \\
\hline 8 & 79.78 & 0.60 & 11.61 & 1.30 & 0.01 & 0.35 & 0.03 & 0.08 & 0.52 & 0.04 \\
\hline 9 & 69.17 & 0.90 & 17.93 & 2.07 & 0.01 & 0.51 & 0.02 & 0.06 & 0.82 & 0.02 \\
\hline 10 & 74.38 & 0.80 & 15.50 & 1.82 & 0.01 & 0.47 & 0.06 & 0.06 & 0.75 & 0.02 \\
\hline 11 & 76.17 & 0.70 & 14.16 & 1.81 & 0.01 & 0.39 & 0.04 & 0.08 & 0.63 & 0.03 \\
\hline 12 & 76.73 & 0.74 & 14.78 & 1.72 & 0.01 & 0.42 & 0.03 & 0.06 & 0.65 & 0.01 \\
\hline 13 & 72.10 & 0.80 & 16.94 & 1.83 & 0.01 & 0.49 & 0.03 & 0.07 & 0.76 & 0.02 \\
\hline 14 & 75.73 & 0.78 & 15.15 & 1.93 & 0.01 & 0.46 & 0.02 & 0.06 & 0.68 & 0.01 \\
\hline 15 & 69.63 & 0.90 & 17.81 & 1.99 & 0.01 & 0.49 & 0.03 & 0.06 & 0.79 & 0.02 \\
\hline \multicolumn{11}{|l|}{ Brick } \\
\hline 1 & 59.08 & 1.10 & 20.94 & 3.36 & 0.02 & 0.48 & 0.03 & 0.06 & 0.63 & 0.05 \\
\hline 2 & 54.44 & 1.26 & 29.67 & 5.43 & 0.02 & 1.20 & 0.03 & 0.03 & 0.33 & 0.05 \\
\hline 3 & 56.64 & 1.07 & 21.44 & 4.02 & 0.02 & 0.27 & 0.03 & 0.09 & 0.68 & 0.05 \\
\hline 4 & 64.89 & 1.02 & 24.09 & 2.41 & 0.02 & 0.66 & 0.04 & 0.09 & 0.50 & 0.03 \\
\hline 5 & 64.80 & 0.95 & 22.04 & 2.81 & 0.02 & 0.70 & 0.48 & 0.12 & 0.57 & 0.06 \\
\hline 6 & 62.99 & 0.84 & 23.71 & 2.23 & 0.02 & 0.52 & 0.03 & 0.06 & 0.43 & 0.04 \\
\hline 7 & 64.46 & 0.81 & 18.93 & 4.21 & 0.02 & 0.28 & 0.03 & 0.08 & 0.82 & 0.04 \\
\hline 8 & 62.91 & 1.09 & 25.84 & 2.43 & 0.02 & 0.73 & 0.01 & 0.04 & 0.23 & 0.03 \\
\hline 9 & 61.83 & 1.11 & 25.66 & 2.37 & 0.02 & 0.69 & 0.01 & 0.04 & 0.23 & 0.03 \\
\hline 10 & 61.67 & 0.96 & 18.91 & 4.30 & 0.02 & 0.32 & 0.02 & 0.07 & 0.76 & 0.03 \\
\hline 11 & 70.77 & 0.81 & 18.62 & 1.29 & 0.02 & 0.20 & 0.03 & 0.12 & 0.42 & 0.03 \\
\hline 12 & 62.46 & 0.89 & 20.61 & 2.92 & 0.02 & 0.70 & 0.03 & 0.07 & 0.89 & 0.03 \\
\hline 13 & 62.28 & 0.93 & 20.38 & 3.14 & 0.02 & 0.33 & 0.03 & 0.10 & 0.81 & 0.04 \\
\hline 14 & 65.79 & 0.76 & 21.43 & 1.63 & 0.02 & 0.26 & 0.06 & 0.11 & 0.64 & 0.04 \\
\hline 15 & 68.20 & 0.96 & 21.87 & 2.40 & 0.02 & 0.67 & 0.02 & 0.04 & 0.10 & 0.02 \\
\hline
\end{tabular}




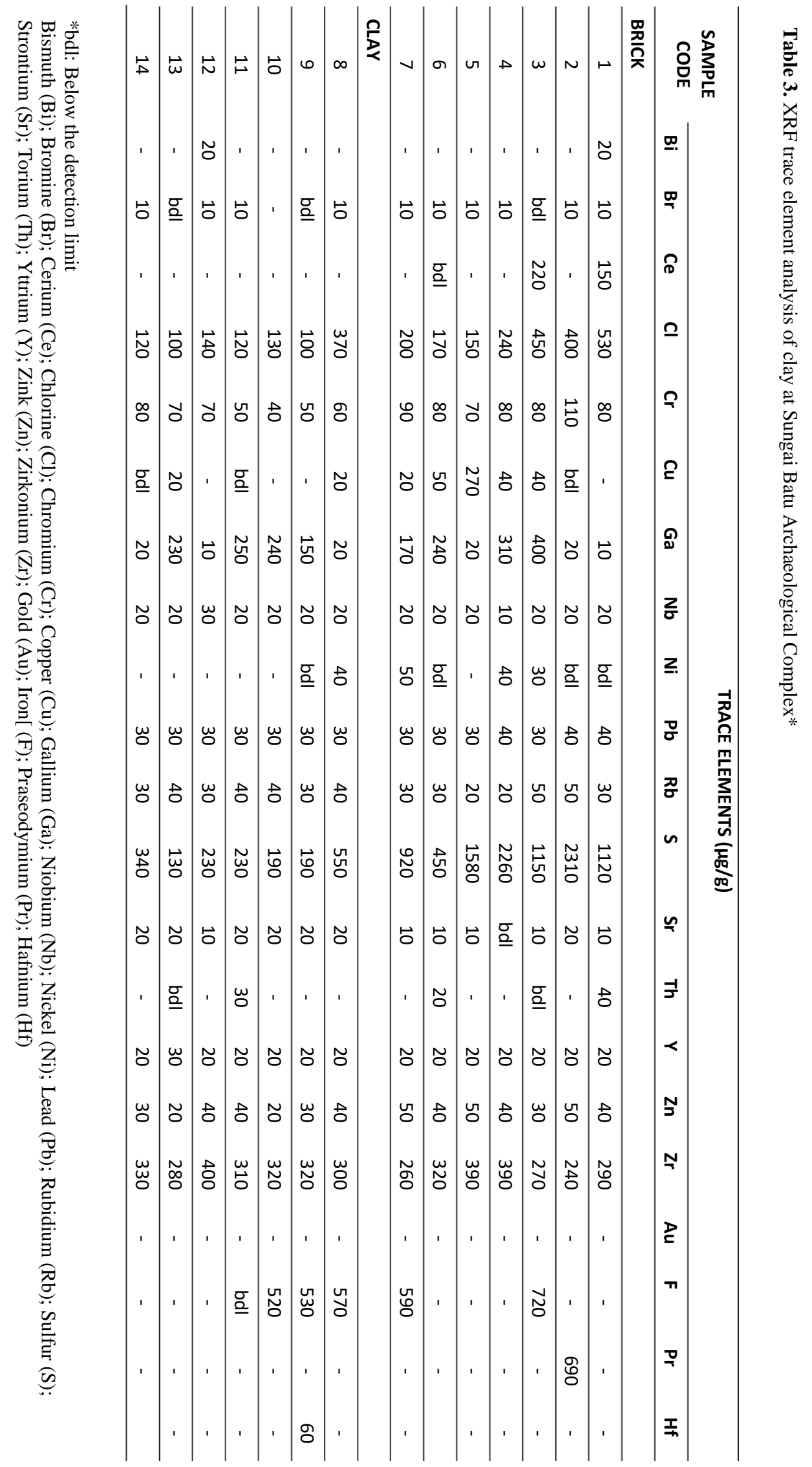




\section{CONCLUSION}

Field research involving survey, mapping, and core drilling data have helped interpret the potential of the Sungai Batu Complex area in developing the world's iron smelting industry. The abundance of earth materials such as iron ore, magnetite, hematite, and mangroves as many fuels is beneficial in developing iron-based industries in this area. In addition, the presence of a deep river that is about 100 meters wide and 30 meters deep also allows merchant ships to travel up to this area.

The abundance of alluvial sediments also allows local wisdom related to brick making and the construction of jetty structures to facilitate trade. Analysis of survey and core drilling data also provides important information that the people of Kedah Tua, especially in the Sungai Batu Archaeological Complex area, have extensive knowledge related to paleoenvironment disciplines. This knowledge let the people of Kedah Tua select the most potential area to be the main trading center of Kedah Tua since 788 BC.

\section{ACKNOWLEDGEMENT}

This study was conducted under the grant of "Sungai Batu Archaeological Study (1001/PARKEO/870007)." Thanks to Dato Professor Dr. Mokhtar Saidin, Director of Pusat Penyelidikan Arkeologi Global for guidance and advice during this study. In addition, the assistance from staff and fellow researchers who are directly and indirectly involved in this research is also thanked.

\section{REFERENCES}

Ahmad, N. (2016). Kajian Arkeologi di Tapak SB1R, SB1S, SB1T, SB1U, SB1V dan SB1Z di Kompleks Sungai Batu, Lembah Bujang, Kedah. Pulau Pinang: Doctoral dissertation Universiti Sains Malaysia.

Almashoor, S. S. (1974). Geology of Gunung Jerai, Kedah. Kuala Lumpur: Thesis Universiti Kebangsaan Malaysia.

Andika, F., Saad, R., Saidin, M. M., Muztaza, N. M., \& Amsir. (2018). Identification of Sungai Batu Sediment using 2D Resistivity Imaging and Seismic Refraction Methods for Ancient River Mapping at Kedah, Malaysia. Journal of Physics: Conference Series, 995(1), 012088.

ArcGIS Database. (2019). GEBCO 2019 Basemap (NOAA NCEI Visualization). Retrieved April 2, 2020, from ArcGIS Hub website: http://hub.arcgis.com/datasets/

Bradford, E. F. (1972). The geology and mineral resources of the Gunung Jerai area, Kedah. Ipoh: Geological Survey Headquarters.

Hoyland, R. G., \& Gilmour, B. (2006). Medieval Islamic Swords and Swordmaking: Kindi's Treatise "On Swords and Their Kinds. ” Oxford: Gibb Memorial Trust.

I-Tsing. (1896). A Record of The Buddhist Religion as Practised in India and The Malay Archipelago (A.D. 671-695) (J. Takakusu, Ed.). Oxford: The Clarendon Press.

Ihsan, S. R., Nordiana, M. M., Saad, R., Saidin, M., Maslinda, U., Hisham, H., \& Sulaiman, N. (2015). Investigation of Ancient River at Lembah Bujang, Kedah, Malaysia. The Electronic Journal of Geotechnical Engineering (EJGE), 20(11), 4385-4392.

Naizatul, A. M. (2012). Ekskavasi Tapak Peleburan Besi SB2A, Sungai Batu, Lembah Bujang. Pulau Pinang: Thesis Universiti Sains Malaysia.

Naizatul, A. M., \& Saidin, M. (2018). Sumbangan Lembah Bujang terhadap Industri Besi di Malaysia. Melayu: Jurnal Antarabangsa Dunia Melayu, 11(2), 183-200.

Naizatul, A. M., \& Saidin, M. (2019). Artifak Besi dalam Industri Besi Sungai Batu, Lembah Bujang. In Arkeologi Kedah Tua: Sumbangan Data Terkini dari Perspektif Warisan, Seni \& Budaya (pp. 17-32). Pulau Pinang: Pusat Penyelidikan Arkeologi Global, Universiti Sains Malaysia.

Ngadenin, N., Indrastomo, F. D., Karunianto, A. J., \& Rakhma, E. (2017). Geologi dan Identifikasi Cebakan Bijih di Daerah Batubesi, Belitung Timur. Eksplorium, 38(1), 7 18.

Saidin, M. (2016). Kedah Tua Kingdom: New Evidence from Sungai Batu Complex. Kedah Tua International Conference. Sungai Petani, Kedah: Centre for Global Archaeological Research, Universiti Sains Malaysia.

Sathiamurthy, E., \& Voris, H. K. (2006). Maps of Holocene Sea Level Transgression and Submerged Lakes on the Sunda Shelf. The Natural History Journal of Chulalongkorn University, Supplement(August), 1-43.

Talib, N. K. (2009). Laporan Awal Penggerudian Sungai Batu, Lembah Bujang, Kedah. Pulau Pinang: Universiti Sains Malaysia.

Thilakavathy, M. (2019). SANGAM TAMILS: With Special Reference To Paţ̧inapālai. New Delhi: MJP Publishers.

Yusoh, R., Saad, R., Saidin, M., Muhammad, S. B., Anda, S. T., Ashraf, M. A. M., \& Hazreek, Z. A. M. (2018). Visualizing Sungai Batu Ancient River, Lembah Bujang Archeology Site, Kedah - Malaysia using 3-D Resistivity Imaging. Journal of Physics: Conference Series, 995(1), 012117. 
Yusoh, R., Saad, R., Saidin, M., Muhammad, S. B., Anda, S. T., Ismail, M. A. M., \& Hazreek, Z. A. M. (2018). Identifying Resistivity Anomalies of Sungai Batu Ancient River using 3D Contour Map. Journal of Physics: Conference Series, 995(1), 012116.

Zolkurnian, H. (2009). Laporan Akhir Tapak SB1A, Kompleks Sungai Batu, Lembah Bujang, Kedah. Pulau Pinang: Pusat Penyelidikan Arkeologi Global, Universiti Sains Malaysia. 